\title{
ABSTRACT
}

Biblical Creation versus evolution has been an acrimonious issue for well over a century between religious conservatives, especially Protestant fundamentalists and those people who consider parts of the Bible - particularly the Book of Genesis - to be allegorical and symbolic. During the nineteenth century the idea that the Bible gave a directly true account of the origins of the world was deeply affected by scientific discoveries. The new sciences of geology, and later of astronony, made it overwhelmingly probable that the physical world is of infinitely greater age than the few thousand years contemplated by the biblical account. The science of biology developed an account of the evolution of the various species of living organisms. Early fundamentalism was savagely hostile to the theory of evolution. In the mid-twentieth century the strife over this question seemed to have died down; but in the seventies and eighties hostility to evolution flared up again, and theories of 'creationism' were deployed. Though creationism attempts to argue with scientific arguments against evolution, it is hardly to be doubted that the mainspring of its motivation lies in biblical fundamentalism: that is, people are creationists because they think that the theory of evolution contradicts scripture and that creationism agrees with it.

Scientific creationists believe that their creation model makes better sense of the facts of earthly phenomena than does the evolution model. From this position many scientific creationists have been lobbying for the presentation of both models in school science classes in the USA. Their insistence on a literal reading of the Bible is both a test of faith and the sole basis for faith. They accept the accuracy of the Bible a priori. Observations must be wrestled with until they can be fitted to the biblical statements. Geological phenomena such a rock strata and fossils inust be evidence of the Noachian flood, since evidence should be out there and the Bible describes no other event so likely to leave such massive deposits. New species cannot have arisen by natural selection or any 
other mechanism because the Bible states that God created each kind of organism.

The scientific creationist strategy is to attempt to find discrepancies in the evidence and logic supporting the evolutionary theory and to show that such problems are avoided if one accepts the literal interpretation of Genesis. Evidence that is said to strongly support their view includes the laws of thermodynamics and the scarcity of transitional fossils. But they do not rely upon tangible evidence in favour of their views so much as they seek to undermine evolution. The evolution model is rejected by them because it does not match a literal reading of the Book of Genesis and the special creation model is embraced despite its problems with facts. This point is why scientific creationism is a religious concept, even if it is presented without using the word "God" or quoting scripture. It is religious, because religious doctrine and not scientific fact has been used to make the basic choices which have formed the "model".

On the matter of religion and science, it needs to be said that there is no real incompatibility between the two. There is no incompatibility between a belief in God and the belief that evolution is the means by which all living things have come into being. That evolution is beyond all else a creative process has never been doubted by anyone acquainted with the facts.

\section{SKEPPING DEUR EVOLUSIE}

Om die verloop van die ontwikkeling van lewe, soos byvoorbeeld deur Jordaan $\varepsilon$ Loots (1984) uiteengesit is, te aanvaar, is vir baie mense nie moontlik nie, omdat dit indruis teen hulle opvatting van wat in Genesis aangaande die Skepping staan. Dit is ook moeilik om lank gehuldigde opvattings te wysig, nie slegs uit eerbied vir die Bybel nie, maar ook omdat mense vrees dat dit gevolge sal hé ten opsigte van die res van die Bybel sodat uiteindelik selfs die evangelie van Christus in sy wese aangetas sal word. Soos Lever (1969) dit stel: Weerstand teen 'n aanvaarding van miljarde jare ouderdom van die aarde en van 'n afstamming van die mens uit die diereryk, spruit voort uit 'n besorgdheid dat hiermee die Bybelse openbaring en die Christelike geloof in die hart geraak en verander word. Nou is dit so dat daar persone is - ook baie 
Christene - wat direk of indirek met die kennis en insigte van die moderne natuurwetenskap in aanraking kom en as gevolg daarvan sekere aannames maak wat nie met vroeëre opvattings cor die ontstaan van die aardse werklikhede ooreenstem nie. Daarmee wil hulle bepaald nie die Bybelse openbaring en die evangelie van Christus verwerp nie. Nee, juis omdat hulle glo dat hierin die essensiële waarde van ons lewe geleë is, meen hulle dat in ander interpretasie, in ander begrip van die betekenis van hierdie Bybelgedeelte nie slegs noodsaaklik is nie, maar ook moontlik en selfs verrykend moet wees.

Dit wil nie sê dat 'n mens nie begrip het vir die meer behoudende (fundamentalistiese) standpunt nie. Baie van ons het dit ook vroeër gehuldig, maar deur verdieping in die probleem van mening verander. Ons kan dus met Lever wat dieselfde ervaring gehad het, saamstem: "Samen met vele anderen heb ik dat als een bevrijding ervaren want dan ga je er meer oog voor krijgen dat het Christelijk geloof - beter nog: het evangelie van Christus - niet alleen voor het persoonlijk geloofsleven en binnen de muren van de kerk van betekenis is, maar ook uitzichten biedt voor de grote vraagstukken van deze tijd en voor de toekomst van de mensheid" (1969, p9).

'n Studie van die bestaande literatuur oor evolusie bring 'n mens dadelik onder die indruk van die gekompliseerdheid van die evolusievraagstuk. Ons het te make met 'n enorme hoeveelheid gegewens, met teorieë en hipoteses wat nog in 'n stadium van - soms hewige - diskussie is en met gevolgtrekkings wat soms buite die enger gebied van die vakwetenskaplike denke val. Geloof en lewens- en wèreldbeskouing speel beslis cok belangrike rolle. Die wèreldbeskouing word nie slegs vanuit die natuurwetenskaplike sfeer beïnvloed nie, maar die omgekeerde is ook waar. Probleemstellings, teorieë en hipoteses kan deur die lewens-en wèreldbeskoulike standpunt van die ondersoeker beīnvloed word. Daarom is dit belangrik dat ons onsself die vraag moet afvra wat die Christen glo betreffende die ontstaan van organismes en in watter mate die geloof sy invloed op die vakwetenskaplike denke uitoefen. Dit wil sê, die vraag is hoe ver moet die Bybel geld ten opsigte van ons denke aangaande die onrsprongrraag. Gee die Bybel ons slegs algemene riglyne vir ons lewens- en wèreldbeskouing of ook maatstawwe vir die beoordeling van teorieë en hipoteses, of is dit selfs so dat die Bybel aan ons gegewens 
verstrek waaraan ons ons moet hou wanneer wetenskaplike werk gedoen word? Dit is belangrike vrae vir 'n bespreking van die evolusieproses.

\section{FUNDAMENTALISTIESE SIENING}

Die fundamentaliste huldig die mening dat Genesis ons nas die skeppings - en heilsverkondiging wel deeglik wetenskaplik eksakte kennis aanbied, sodat die bioloog wat in die Bybel glo nie alleen Bybel en vakwetenskap met mekaar moet konfronteer nie, maar selfs die waarheid van die wetenskaplike gegewens letterlik moet afmeet volgens die mededelinge in die Bybel. Dit is ' $n$ mening wat voortspruit uit ' $n$ ekstreme aanpassing van die interpretasie van die eerste hoofstukke van die Bybel wat op die stand van die natuurwetenskap van 'n paar eeue gelede gebaseer is. Volgens hierdie opvatting is Genesis geskryf in vakwetenskaplike taal, maar dit val onmiddellik plat as 'n mens nagaan wat die eintlike betekenis van die "terme" dae, aard (soort) en aarde is en was (Barr, 1984).

'n Opvallende fout in die fundamentalistiese aanpak van die ontstaanprobleem is dus daarin geleë dat hulle begin deur Genesis te lees asof dit met gebruikmaking van natuurwetenskaplike begrippe geskryf is, om dan vervolgens die rolle om te ruil deur die op hierdie wyse omgevormde tekste normatief vir die wetenskap te stel. Wanneer 'n mens een maal ingesien het dat die natuurwetenskaplike begrippe op menslike interpretasies berus, dan sien in mens ineens duidelik dat met hierdie metode sowel die Bybel verkeerd gelees word asook die wetenskap ongeoorloof aan bande gelè word (Lever, 1956).

As in ag geneem word dat die volgorde van Genesis 1 op verskeie punte nie ooreenkom met dit wat deur die huidige natuurwetenskap gestel word nie, dat elke bioloog sal erken dat ons ons insigte voortdurend wysig, en ook dat die volgorde van Genesis 2 nie dieselfde as in Genesis 1 is nie, dan verval die sogenaamde "bewyse" van die fundamentaliste dat hulle interpretasie - en slegs hulle interpretasie - reg is. 'n Mens sien ook dat binne hierdie fundamentalistiese denkwyse daar vir die geloof rampspoedige moontlikhede bestaan dat die "bewyse" van die teendeel ook gelewer kan word. Dit lé die gevaarlike kern van die fundamentaliste 
bloot, naamlik die kardinale fout dat dit die juistheid van die geloof as eksak bewysbaar stel, wardeur geloof en verstand enersyds, en openbaring en wetenskap andersyds, volkome in mekaar se vlakke te lê kom. Dit het 'n beredeneerde geloof en 'n onwaaragtige wetenskap tot gevolg; met geloofstwyfel en ongeloof as eerlike konsekwensies (Lever. 1956).

Die vraag is dus: kan geloof en wetenskap geskei word? Schuurman (1980) stel dit so: "Man the creature investigates with the aid of science the totality of God's creation. To engage in science is one of many activities of man. To believe is another activity. Neither can be reduced to the other". Voorts sè hy tereg dat wat Hebreërs 11:1 van geloof sè nie op wetenskaplike denke toegepas kan word nie: Om te glo, is om seker te wees van die dinge wat ons hoop, om oortuig te wees van die dinge wat ons nie sien nie. Bogenoemde mistasting (in wetenskaplike sin) van die fundamentaliste (wat dikwels te goeder trou gemaak word) beteken egter nie dat ons nie 'n oop gemoed moet hè nie; die bron waaruit redenering voortspruit is nog 'n gelowige en nougesette vashou aan die Bybel as die Woord van God vir die volle lewe - en dus ook vir elke vertakking van die wetenskap.

In Genesis gaan dit dus oor die werklikheid wat ons wetenskaplik kan ondersoek, en gegewens word aan ons meegedeel wat ons nie op 'n wetenskaplike wyse kan ontdek nie. Die Bybel sê slegs dat iets gebeur het, maar nie hoe dit gebeur het nie; laasgenoemde aspek lè soms op die terrein van die wetenskap. Die Bybel gee aan ons die hoogtepunte; die wetenskap kan soms die dele tussenin ontdek. Dit kom dus daarop neer dat Genesis geskryf is om aan ons die werklikheid te openbaar wat vir ons van ewigdurende fundamenteel-religieuse betekenis is en wat nie deur wetenskaplike ondersoek ontdek kan word nie. Hierdie geopenbaarde werklikhede moet ons dankbaar aanvaar en nornatief aan die grondslag van ons denke - insluitende ons natuurwetenskaplike denke - koppel.

Vroeëre uitsprake. Dit is nou al eeue dat baie mense daarvan oortuig is dat godsdiens en natuurwetenskap aan teenoorgestelde pole in die kulturele evolusie van menslike intelligensie staan. Volgens hierdie siening word primitiewe religieuse bygelowe geleidelik maar onlierroeplik 
verplaas deur empiries-gebaseerde wetenskaplike gevolgtrekkings. Alhoewel die meeste geleerdes die positivistiese aspekte laat vaar het, is die konsep van 'n wesenlike konflik tussen natuurwetenskap en godsdiens' so onuitwisbaar op die kollektiewe intelligensie van moderne mense afgedruk, dat dit moeilik gaan om dit verplaas te kry. Hierdie polarisering het ' $n$ lang geskiedenis en het in die verlede kort-kort in hewige twisgeskrifte opgevlam.

Neëntig jaar gelede (1896) het Andrew White, die eerste president van Cornell Universiteit in die VSA, sy tweevolumewerk A history of the warfare of science with theology in Christendom gepubliseer. In hierdie volumes het hy die antagonismes tussen religieuse en natuurwetenskaplike sienings deur die eeue opgeteken en tot die volgende gevolgtrekking gekom ( $p$ viii): "In all modern history, interference with science in the supposed interest of religion, no matter how conscientious such interference may have been, has resulted in the direst evils both to religion and to science, and invariably; and on the other hand, all untrammeled scientific investigation, no matter how dangerous to religion some of its stages may have seemed for the time to be, has invariably resulted in the highest good both of religion and of science".

In 'n bekende biologietydskrif (Quarterly Review of Biology, vol 58:391, 1983) skryf die redaksie die volgende aangaande hierdie onderwerp: "Modern historians of science believe that the conception of an obdurate warfare between science and theology, in particular of a supposedly irreconcilable conflict between the acceptance of organic evolution and a religious faith in a divine creation of the universe and life on earth, is greatly overwrought. From the time of Darwin until now, the majority of theologians, conservative and liberal alike, have had no difficulty in harmonizing the theory of evolution with a belief in God as Creator. Many scientists, too, continue to hold a faith in a creative deity while fully convinced both of the reality of evolution and of the action of natural selection as a major agency in bringing it about. Nevertheless, there continues to exist in the United States and to some extent in a few other countries a strong current of religious fundamentalism".

Grondslag van verengde siening 
Dit is moeilik om in alle gevalle die grondslag van 'n verengde siening en interpretasie van die Bybel te bepaal, maar 'n mens kan aanvaar dat dit verband hou met 'n opvatting dat die Bybel letterlik as onfeilbaar beskou moet word. Marsden (1983) is van mening dat dit aan die sameloop van twee kragtige tradisies gekoppel kan word, naamlik millenarianisme en protestantse skolastisisme.

Millenarianisme (Chiliasme). Dit is die leer van 'n duisendjarige vrederyk op aarde volgens in letterlike opvatting van Openbaring 20 . Die moderne premillenniale sienings wat sedert die neëntiende eeu deur verskillende kerkgroepe gehuldig is, word op die presiese interpretasies van die getalle in die Bybelse profesieè gebaseer. Hierdie chialiste aanvaar dat die Bybel hom leen vir eksakte wetenskaplike ontleding op grond warvan minstens sommige aspekte van die toekoms presies voorspel kan word. Omdat dit vir hulle belangrik is om 'n Skrifuitlegging te hê wat presiese gevolgtrekkings oplewer, word, byvoorbeeld, die eerste hoofstuk van Genesis geïnterpreteer as skepping binne ses dae van 24 uur elk.

Protestantse skolastisisme. 'n Ander sterk tradisie by sekere Protestante wat dikwels eng sienswyses ten opsigte van Genesis 1 ingehou het, is Protestantse skolastisisme. Dit is 'n tradisie wat veral deur teoloë van Princeton, VSA, soos Benjamin Warfield, voorgestaan is (Marsden, 1983): Omdat die Bybel die Woord van God is, moet dit akkuraat wees ten opsigte van wetenskap en geskiedenis asook ten opsigte van leerstellings; dit beteken nie dat alles in die Bybel letterlik geinterpreteer moet word nie, maar die wetenskaplike korrektheid van Bybelse "stellings" moet vooropgestel word. 'n Goeie voorbeeld hiervan is die Lutherse Kerk se Missouri-sinode. Waarskynlik om redes wat verband gehou het met hulle Protestantse skolastiese tradisie, asook met in immigrantegroep se vasbeslotenheid om nie deur Amerikaanse teologie besmet te word nie, het die teoloë wat 'n leidende rol gespeel het, dwarsdeur die eerste helfte van die 20ste eeu, op 'n ultrakonserwatiewe siening van die Skrif aangedring. Ondat God deur die Heilige Gees met presiesheid in die Bybel spreek, het die Missouri-sinodegangers besluit dat die dae wat in die eerste hoofstuk van Genesis beskryf word, 24 uur lank moet wees. Evolusie was dus ateisties en immoreel, en teïstiese evolusie was dus in stryd met sowel die Skrif as met ware evolusie. Toe Henry Morris in 1963 die kreasiewetenskapbeweging gestig het, het hy genoeg bondgenote $-18-$ 
uit die Missouri-sinodegroep gekry om 'n derde van die oorspronklike reëlingskomitee uit te maak.

\section{DIE SOGENAAMDE KREASIEWETENSKAP}

In die VSA (soos moontlik ook in die RSA) word biologiese evolusie nog deur baie mense beskou as die teenoorgestelde van goddelike skepping en dus onversoenbaar met die tradisionele Christelike geloof. Hierdie vereenvoudigde sienswyse kom so wydversprei in die VSA voor dat die sogenaamde kreasioniste dit reggekry het om die owerhede van twee State te oorreed om wette te aanvaar wat verseker het dat "skeppingswetenskap" saam met evolusie in openbare skole as deel van biologie gedoseer word (Cooke, 1983; Lewin, 1984; Montagu, 1984). Hierdie kreasioniste is fundamentaliste wat aandring op in letterlike interpretasie van die Genesis-weergawe van die Skepping (Miller, 1984); terselfdertyd dring hulle daarop an dat hulle verklaring van die verskeidenheid van lewe op aarde as 'n wetenskaplike teorie ekwivalent aan die evolusieteorie beskou moet word en dat dit in terme van aandag ewe veel tyd in die biologieklaskamer moet kry (Root-Bernstein, 1984; May, 1984). Volgens hierdie kreasiewetenskaplikes is daar slegs 'n keuse tussen hulle standpunt van letterlike interpretasie en die evolusieteorie wat uit die bose is. Hulle bepleit nie skepping in die algemene sin van geloof in 'n Goddelike skepping nie, mar verdedig net een siening van skepping, naamlik dat die aarde binne ses dae van 24 uur elk geskep is en slegs in paar duisend jaar oud is. Hierdie letterlike interpretasie van die Skrif sluit natuurlik enige soort biologiese evolusie uit.

Protes teen bogenoemde wette is deur Protestantse, Rooms Katolieke en Joodse individue en organisasies, sowel as deur opvoedkundige instansies aangeteken en die aanname van die wette is in 1982 deur in hof ter syde gestel (Ruse, 1984; Lyons, 1984; Overton, 1984). Volskaalse pogings word egter nog deur die fundamentaliste aangewend om hulle standpunte in wetgewing vasgelè te kry. Al hierdie pogings het ook 'n reaksie van skrywers uitgelok om teen die fundamentalistiese uitsprake beswaar te maak en die onhoudbaarheid van hulle standpunte te beredeneer (Gillespie, 1979; Futuyma, 1983; Montagu, 1984; Mayer, 1984; Godfrey, 1985a).

$-19-$ 
Dit is duidelik dat die "kreasiewetenskaplikes" se gevolgtrekkings op die Bybel as gesag en as teksboek gebaseer is. Verskeie organisasies is in die VSA gestig om hierdie standpunt uit te dra. Die grootste kreasieorganisasie is die Institute for Creation Research (ICR) in San Diego, en aan die hoof hiervan staan Henry Morris, Ph.D. 'n hidroliese ingenieur. Sy uitgangspunt (1966) is dat: "If man wishes to know an$y$ thing at all about creation ... his sole source of true information is that of divine revelation". Morris en sy volgelinge stem saam dat dit duidelik is dat die eerste hoofstuk van Genesis na skeppingsdae van 24 uur elk verwys en evolusie as 'n moontlikheid dus heeltemal uitskakel. Sy uitspraak oor evolusie (1972a) is soos volg: "Evolution is the root of atheism, of communism, nazism, behaviourism, racism, economic imperialisn, libertinism, anarchism and all manner of anti-Christian systems of belief and practice".

Getrou aan sy agtergrond is Morris lief om teorieë aangaande die sondvloed op te stel. Volgens hom bied die sondvloed 'n nuwe en kragtige stelsel om wetenskaplike gegewens wat op die aarde se vroeë geskiedenis betrekking het, te verenig en te korreleer. Hy suggereer ook dat die diere wat in Noag se sorg was in torpor ('n soort slaap) gehou is deur "divenely-ordered genetic mutations experienced by the individuals selected for presentation in the Ark, equipping them with the capacities for migration and hibernations" (1978). Voorts beweer hy dat: "The so-called geologic ages are essentially synonymous with the evolutionary theory of origins. The latter is the anti-God conspiracy of Satan himself" (1972b).

Professor Gary Parker staan aan die hoof van die afdeling Biologie in die Institute for Creation Research, 'n persoon met 'n doktorsgraad in opvoedkunde. Sy spesialiseringsrigtings sluit in die ekologiese aspek van Noag se ark, en die identifisering van fossielvoetspore. Oor die eerste onderwerp het hy Dry bones (1980) gepubliseer waarin hy die teenwoordigheid van 'n volle komplement van fauna, insluitende dinosouriërs, in Noag se ark beskryf. In Whitcomb \& Morris (1980) se The Genesis flood - wat in die eerste jaar 24 herdrukke beleef het - word beweer dat daar vir presies 522 treintrokke in die ark plek was. Volgens -20 - 
Jukes (1984) bereken prof. K. Padian van die ICR dat daar 300 genera van die Dinosauria in die ark was en dat hulle grootte gewissel het van dié van 'n klein olifantjie tot diere met 'n massa gelykstaande aan dié van 30-40 olifante. Soortgelyke berekeninge van hoe al die verskillende diersoorte in die ark kon inpas, is ook deur Segraves (1975) gemaak; hy het selfs vir elk van 850000 insekspesies twee duim vliergruimte gegee. Parker sluit sy boek Dry bones met die volgende stelling af: "And we hope that you, too, wil try to see God's world through God's eyes. The heavens declare his glory; the fossils show the power of His judgment".

Benewens die ICR bestaan in die VSA ook die Creation-Science Research Center (CSRC) wat hoofsaaklik toegespits is op die opleiding van onderwysers. Volgens hulle huidige hoof, mnr. Kelly Segraves, gaan hy hom beywer om alle skoolleerboeke waarin iets van evolusie voorkom, uit te skakel. Volgens Jukes (1984) sou Segraves eerder wou sien dat sy eie geskrifte voorgeskryf word warin hy onder meer sy eie weergawe gee van hoe die twee kangeroes wat in die ark was hulle pad vanaf Armenië oor die verwoeste aardoppervlak na Australië gevind het (Kofahl \& Segraves, 1975, p221).

Kreasiewetenskapbeweging

Die hoofdoel van die stigting van die kreasiewetenskapbeweging was "om 'n vaste rasionele en wetenskaplike grondslag vir Christengeloof daar te stel". In sy eerste boek (19.46) illustreer Morris "the great number of scientific truths that have lain hidden within its pages for $\mathbf{3 0}$ centuries or more, only to be discovered by man's enterprise within the last few centuries or even years". Hierdie "feite" sluit onder meer stellings in soos dat "die sterre nie getel kan word nie", en dat die psalms direk verdamping, wind en elektriese ontladings as die oorsaak van reën beskryf. (Psalm 135:7 - Hy laat die wolke opkom oor die horison, Hy maak die weerligstrale vir die reën en bring die wind te voorskyn.) Die kreasiewetenskapbeweging se lede gaan uit hulle pad om besliste getuienis te soek wat Bybelse stellings staaf. Hulle beskou die Bybel dus as vol van wetenskaplike verklarings wat op dieselfde wyse as dié in 20 ste eeuse wetenskaplike publikasies aangebied word. Hierdie benadering is reeds 
vir baie dekades gevolg, maar dit is eers redelik onlangs op so 'n georganiseerde grondslag gedoen.

Toe Andrew White (1896) sy twee volumes oor die konflik tussen wetenskap en teologie geskryf het, het hy gemeen dat die ou stryd tussen religieuse konserwatiewes en natuurwetenskaplikes iets van die verlede was. Hy was natuurlik verkeerd, en Amerikaners was verstom om in 1925 te ontdek dat die stryd nog voortgaan. Die stydbyle is in daardie jaar uitgehaal toe 'n toetssaak teen 'n 24 jarige onderwyser, John Scopes, in Dayton. Tennessee, ingestel is omdat hy evolusie in die skool "verkondig" het: hy is skuldig bevind en in boete van 100) dollar opgele. Hierdie wet is eers na 40 jaar herroep toe dit as onkonstitusioneel deur die Hooggeregshof van die VSA bevind is.

Sedert die Scopes-verhoor was dit relatief stil ten opsigte van aggressiewe optredes deur fundamentaliste. In die sestigerjare is egter 'n nuwe veldtog van fundamentalisme (kreasionisme) van stapel gestuur sodat daar vandag benewens die reeds genoemde Kreasie-institute nog institute, kolleges, verenigings en klubs dwarsoor die VSA is wat van hulle lede verwag dat hulle die Genesis-weergawe van die Skepping en die sondvloed as letterlike geskiedenis moet aanvaar. Die leiers van hierdie groepe bestaan enersyds uit opregte plaslike predikante wat werklik (maar verkeerdelik) ontsteld is as gevolg van die idee dat nuwe wetenskaplike kennis onvermydelik tot 'n verlaging van moraal en sedelike verval sal lei, en andersyds uit televisie-evangeliste en woordvoerders van die New Right and Moral Majority wat meer polities gemotiveerd is (Newell, 1982).

Dit moet duidelik gestel word dat die probleem nie skepping versus evolusie is nie, maar wetenskaplike kreasionisme versus evolusie. Morris (1974) beweer in sy boek Scientific creationism dat skepping deur hulle behandel word "solely on a scientific basis". Kreasiewetenskap is eintlik slegs "n slagwoord deur die term "wetenskap" met "kreasie" te verbind. Die inhoud voldoen egter nie aan die kriteriums vir wetenskap nie, want dit impliseer dat aan 'n Skepper geglo word, terwyl die voorstanders ontken dat dit religieus is. Daarom gaan die hele kwessie hier on wetenskaplike kreasionisme (nie die Christelike teologie van skepping nie) teenoor evolusie. Die teoloog Leonard Kenkel (1985) spreek hom soos 
volg in hierdie verband uit: "Contrary to its claim, Scientific Creationism is a sectarian religious doctrine in the guise of science demanding to be taught in the science classroom as science". En daarin is die probleem geleë. Ons het dus hier met drie aangeleenthede te make: die teologie van skepping (godsdiens), evolusie (wetenskap) en kreasiewetenskap (religieuse leerstelling en pseudowetenskap). Teologie sowel as wetenskap maak daarop aanspraak om die waarheid aangaande die wèreld te leer, om in besit te wees van geldige prosesse en inligting, en om die perke van hulle bevoegdhede te ken. Aan hierdie gemeenskaplike aansprake is egter ' $n$ fundamentele begripsverskil gekoppel. Die teologie van kreasie (skepping) is 'n belydenis deur die gelowige dat die hele heelal afhanklik is van God ab initio, vanaf die begin. Teologie soek na die relasie van menslike ondervinding tot tradisies wat in die gelowige se stelsel in heilige gesag het. Teologie kry dus sy primére gegewens uit menslike ondervinding (wat vanuit 'n heilige tradisie soos die Bybel geinterpreteer word) en uiteindelik van God wat openbaar maak. "Religious faith accepts a transcendent, ultimate cause beyond what is observable by the senses" (Kenkel, 1985).

Die wetenskaplike metode, aan die ander kant, is 'n wisselwerking van feite (waarnemings wat deur die sintuie gemaak word) en teorieë (veronderstellings wat verwantskappe tussen feite uitdruk en voorspellings maak wat later verder getoets kan word). in Ware toets van ' $n$ wetenskaplike teorie hang af van verskillende dinge: Dit moet die vermoë hé om wat wargeneem is, te kan verklaar; dit moet kan voorspel wat nog nie waargeneem is nie; dit moet deur verdere eksperimentering getoets kan word; dit moet gewysig kan word met die verkryging van nuwe gegewens. Die feite en teorieë van die wetenskap moet tot stand kom deur eksperimentering en sintese van die onderwerp, hersiening deur vakgenote, en aallvaarding van geldigheid deur die wetenskaplike gemeenskap. Wetenskaplike kreasionisme voldoen beslis nie an hierdie kriteriums nie.

Skeppingsteologie. Skepping soos dit vandag deur die meeste Skrifgeleerdes aangebied en deur die meeste Protestante, Katolieke en Jode aanvaar word, is op 'n geloofsweergawe in die Bybel gebaseer. Die Bybel verklaar slegs dat die wereld deur God geskep is, en om hierdie waarheid te kon oordra, vind uitdrukking van stellings plaas in terme 
van die kosmologie wat in gebruik was ten tye van die skrywer se leeftyd. Met ander woorde die Bybel moet nie ingespan word om 'n aprioristiese standpunt te steun met betrekking tot, byvoorbeeld, die verwerping van evolusie as synde onbybels nie; in so 'n geval spreek die Bybel nie meer tot die mens nie, maar die mens tot die Bybel. Die verskillende Bybelboeke is immers deur verskillende mense, in verskillende omstandighede en tye, en met die beskikbare kennis van hulle tyd geskryf. Genesis is sekerlik net so vol simboliek soos Openbaring, en die volheidsgetal ses (skeppingsdae) kan net so min letterlik vertolk word as die volheidsgetal 144000 in Openbaring. Die Bybel openbaar die wie van die skepping, nie die hoe nie; dị is die laak van die natuurwetenskaplike om die hoe te probeer bepaal. 'n Mens kan dit seker aanvaar dat die outeurs van die Bybel geïnteresseerd was in die "feite" van geskiedenis slegs in soverre as dit die Raadsplan van die Skepper geillustreer het.

Evolusiewetenskap. Die evolusieteorieë is gebaseer op verklarings en idees wat ontstaan het uit feite en wette wat uit verskillende dissiplines afkomstig is: Dierkunde, plantkunde, mikrobiologie, chemie, fisika, astronomie, geologie en die wiskundige dissiplines. Die term feite verwys na dinge wat of direk deur middel van sintuie wargeneem is, ò indirek deur gebruikmaking van uitbreidings van die sintuie, soos mikroskope. chemiese analises ensovoorts (of logiese afleidings wat hieruit gemaak kan word). So byvoorbeeld is natuurlike seleksie in wetenskaplike hipotese wat ' $n$ uitdrukking van verhouding is met betrekking tot goed vasgestelde feite en sekere aannames; dit lei dan tot voorspellings wat verder getoets kan word. Omdat die meganisme van natuurlike seleksie heeltemal natuurlik is en getuienis van toetsings dit aanvaarbaar maak as 'n ondersteunende verklaring, hou dit "i hoë mate van gelcofwaardigheid vir wetenskaplikes in - nie dat natuurlike seleksie die enigste of selfs belangrikste proses in hierdie verband hoef te wees nie.

Evolusie, deur byvoorbeeld natuurlike seleksie, is 'n proses wat binne die natuurlike grense van die wetenskap deur die wisselwerking van feite en teorie tot stand kom. Evolusie (as sodanig) bevestig of ontken nie die bestaan van die Skepper nie. Evolusie (as sodanig) spreek nie vir of teen skepping nie. Evolusie en skepping is nie noodwendig gekoppel nie, maar hulle is nok nie onverenigbaar nie. Evolusie is -24- 
natuurwetenskap. Skepping is geloof (in 'n Skepper). Elk bekyk die oorsprong van plante, diere en veral die mens en die heelal vanuit sy eie perspektief. Soos Kenkel (1985) dit stel: "A person may espouse science, faith, both, or neither".

Die beroemde Amerikaanse genetikus en evolusionis, Theodosius Dobzhansky (1973) het ook sterk te velde getrek teen die standpunt dat skepping en evolusie nie versoenbaar is nie. Hy besluit soos volg: "The organic diversity becomes, however, reasonable and understanding if the Creator has created the living world not by caprice but by evolution propelled by natural selection. It is wrong to hold creation and evolution as mutually exclusive alternatives. I am a creationist and an evolutionist. Evolution is God's, or Nature's method of Creation" (p127). Dit is miskien 'n verrassing vir diegene wat nie Darwin (1859) se Origin of species gelees het nie, dat hy sy boek in min of meer dieselfde trant afsluit: "There is grandeur in this view of life, with its several powers, having been originally breathed by the Creator into a few forms or into one; and that, whilst this planet has gone cycling on according to the fixed law of gravity, from so simple a beginning endless forms most beautiful and most wonderful have been, and are being evolved".

Kreasiewetenskap. Dit kan nie as 'n wetenskap gedefinieer word nie ondat dit gebaseer is op ' $n$ onbuigbare voorveronderstelling, ' $n$ oortuiging wat saamhang met veronderstelde oorsake en gebeure wat nie direk of indirek deur wetenskaplike metodes ondersoek kan word nie. Die gevolgtrekkings gaan die soeke na getuienis vooraf. Daarbenewens kan geen wetenskaplike navorsing ten opsigte van die basiese leerstellings van wetenskaplike kreasionisme gedoen word nie. Openbaring is heeltemal buite die bestek van die natuurwetenskap. Die "navorsing" van die kreasioniste bestaan uit 'n bevooroordeelde, vernietigende kritisering van alle wetenskaplike navorsing wat oor die oorsprong van lewende wesens gedoen word. Die basiese posisie van "wetenskaplike" kreasionisme is negatief, dit wil sé die kreasioniste probeer hulle geloofwaardigheid verstrek deur die opponente te vernietig, en nie deur hulle eie saak op te bou nie. Hulle het uitgevind dat sommige mense hulle bewerings sal aanvaar as hulle dit net genoeg kere inet die regte beklemtoning en plegtigheid herhaal (Newell, 1982). Dit moet ook onmiddellik erken word 
dat sommige evolusioniste hulle in die verlede ook hieraan skuldig gemaak het ten opsigte van die meganismes van evolusie.

In hulle oorlog teen evolusiewetenskap gebruik die kreasiewetenskaplikes die Bybel as 'n simbool, 'n saamtrekpunt bereken om simpatie te bekom en om hulle invloed onder godsdienstige konserwatiewe mense te vergroot. Die Bybel wat die Westerse beskawing gevorm het en die invloedrykste boek van alle tye is, is egter nie 'n plaasvervanger vir sekulère onderrig nie. Onredelike aandrang op in letterlike interpretasie van alle Bybelse stellings lei noodwendig na eindelose konflikte tussen rede en blinde aanvaarding: 'n plat aarde in die middel van die heelal, minder ribbe by mans as by vroue, 'n universele sondvloed en ark wat miljoene plante en diere kon huisves (selfs seediere wat onmiddellik sou doodgaan in varswater) ensovoorts.

Die probleem van die kreasioniste is dus dat hulle nie die wetenskaplike metode kan volg nie. As 'n mens gekompromiteer is tot in vasstaande verklaring (die letterlik Bybelse) en jy word gedwing om alle feite binne hierdie raamwerk in te pas sonder die moontlikheid van afwyking, is iy per definisie onwetenskaplik. Hitching (1982) stel dit so: "However much sympathy we may have for belief in a divine first cause shaping the forces that created the Universe, and however well-meaning the scientific creationists may be, the straitjacket of Genesis $1-11$ is so restricting that to make all evolutionary facts fit within it inevitably ends in a perversion of science" (p 120-1).

Argumente van kreasioniste

Die wesenlike en verreweg oorwegende verskil tussen kreasiewetenskaplikes en evolusioniste is dus die verskil tussen basiese postulate. Die kreasioniste aanvaar die akkuraatheid (in natuurwetenskaplike sin) van die Bybel a priori; met waarnemings moet geworstel word totdat hulle met Bybelse stellings gerym kan word. Geologiese verskynsels soos rotslae en fossiele moet getuienis wees van die sondvloed, want dit is die enigste verklaring wat uit die Bybel gehaal kan word. Nuwe spesies kan nie deur mutasies en natuurlike seleksie of enige ander ontwikkelingsmeganisme ontstaan het nie, want die Bybel verklaar dat God elke soort organisme afsonderlik geskep het. Die Bybel 
beskryf lewensdure van tot honderde jare vir sekere mense (wat tesame in paar duisend jaar is), maar nérens word van miljoene of miljarde jare gepraat nie. Die Bybel vertel ons van degenerasie vanaf die paradystydperk en belowe aan ons die moontlikheid van eventuele verlossing, maar huidige omstandighede bewys dat die wèreld nog steeds in die degenerasiefase is, hoewel die wederkoms van Christus op hande mag wees. In elke van bogenoemde gevalle redeneer die fundamentalis deduktief vanaf sy postulaat dat die Bybelse stelling letterlik waar is.

Om te illustreer hoe die kreasiewetenskaplikes soms die feite kan interpreteer, kan die opeenvolging van werweldiertipes in die aardlae genoem word: Die verklaring is gekoppel aan die sondvloed (sogenaamde vloedgeologie) en berus in 'n hoë mate op beweeglikheid en intelligensie. Die seevisse, wat in die onderste rotslae voorkom, het eerste in die vars reënwater van die vined omgekom. Die stadigbewegende reptiele is toe deur die stygende waters op land uitgewis, terwyl die intelligente diere (soogdiere) die hoogste pieke en rante bestyg het en dus laaste gesterf het; daarom kom laasgenoemdes in die boonste aardlae voor. Daar ward egler nie verklaar hoe die hoër plante (angiosperme) na hoër liggende dele kon "vlug" nie (Miller, 1982). Wat die ouderdom van die aarde betref, word alle bepalings wat deur geoloë gemaak word, verwerp. Morris (1972a) volstaan met die volgende stelling: "The only way we can determine the true age of the earth is for God to tell us what it is. And since He has told us, very plainly, in the Hole Scriptures that it is several thousand years in age, and no more, that ought to settle all basic questions of terrestrial chronology". (Vir 'n bondige bespreking van die metodes wat toegepas word in ouderdomsbepalings van die aarde word die leser na Miller (1984) verwys.)

Op 'n meer algemene vlak redeneer kreasiewetenskaplikes dat volgens die tweede wet van termodinamika evolusie nie kon plasgevind het nie (Kehoe, 1985). Hierdie wet konstateer dat alle veranderings plaasvind in die rigting van toenemende entropie, van toenemende wanorde, van toenemende ewekansigheid, van die afloop van dinge. Die evolusie van organismes hou egter in dat net die teenoorgestelde gebeur (Brooks $\varepsilon$ Wiley, 1984). Vir die meeste bioloë is dit duidelik dat lewende stelsels nie volgens die tweede wet reageer nie, want hulle beweeg in die rigting van toenemende orde, organisasie en kompleksiteit. Daarbenewens besit 
elke lewende wese die vermoë om voort te plant deur kopieë van homself te mak, en elkeen het 'n vorm en organisasie wat klaarblyklik onveranderd bly terwyl sy samestellende dele hulleself hernu. Hierdie unieke kenmerke van lewende stelsels - selforganisering en selfhernuwing - het geen analogie in die nie-lewende wêreld nie. Die vraag is dus wat maak lewende dinge anders? Wat keer dat organismes nie disintegreer nie? Die ortodokse wetenskaplike verklaring is dat 'n lewende wese 'n 'oop' stelsel is - oop vir energie wat van buite inkom en dan vir werkverrigting gebruik word. Dit gaan egter nie altyd op as 'n verklaring nie, en die onvermoë om bogenoemde probleem onder die knie te kry, word deur sommige outeurs toegeskryf aan die ontoereikendheid van klassieke termodinamika om die werking van oop stelsels te verklaar (Hitching, 1982). Ander is van mening dat die tweede wet eintlik as bewys van die geldigheid van die evolusieteorie kan dien. White (1959) glo dat hierdie wet die toestande waarin evolusie plasgevind het uitdruk, met evolusie as in kragtige kumulatiewe krag wat die andersins algemene neiging van energie om verlore te gaan, omkeer.

'n Ander aspek wat dikwels deur kreasiewetenskaplikes na vore gebring word, is die wetenskaplike status van die evolusieteorie: "Neither evolution or ( $\mathrm{sic}$ ) creation is a theory of empirical science .... Evolutionary theories and creationist explanations of the past cannot be falsified by experimental or observational test, even if they are false" (Kofahl. Creation Science Report, 1980 - volgens Williams, 1985). Hierdie bewering van die kreasioniste is gebaseer op ' $n$ in breë kring aanvaarde kriterium om tussen wetenskap en nie-wetenskap te onderskei: om as in wetenskaplike teorie beskou te kan word, moet dit toetsbaar wees (of falsifiseerbaar, volgens filosofiese jargon). Baie outeurs het hulle al uitgelaat oor die moontlikheid al dan nie of die evolusieteorie(ë) toetsbaar is (Mayr, 1961; Popper, 1968; Settle, 1979; Ruse, 1979; Riddiford \& Penny, 1984; Ghiselen, 1984; Williams, 1985; Griesemer, 1985). Na 'n betoog kom Williams tot die volgende gevolgtrekkings: "The creationist claim that evolutionary theory is untestable and is therefore not a legitimate scientific theory is based on a mistaken notion of what sort of prediction is needed to form the basis of a test of a theory. When we understand the types of prediction that can be used in a test of a theory, we discover that tests of evolutionary theory exist and indeed are ubiquitous in the evolutionary literature. Impressively intricate predictions 
of the theory have been tested against observational evidence and have provided confirmatory evidence for the theory. Thus evolutionary theory is not only a legitimate scientific theory, it is also a well confirmed scientific theory". Hiermee stem Popper (1978) - wat eers die teendeel beweer het - tans ook saam. ".. I have changed my mind about the testability and the logical status of the theory of natural selection; and I am glad to have an opportunity to make a recantation" (p345).

\section{SKEPPINGSWONDERS}

Uit in studie van al die verskillende fasette van organiese evolusie blyk dit baie duidelik dat die wondere van die skepping iets so groots is dat daar baie dinge is wat ons nog nie naastenby kan begryp nie. Vanaf sy wasige oorsprong en vroeë manifestasies het lewe langs die kronkelgange van tyd in volle glorie ontplooi tot op die huidige tydstip. Dit is ' $n$ wonderlike verhaal, 'n geskiedenis van miljoene der miljoene individue en van miljoene verskillende soorte in die verloop van duisende miljoene jare. Daar is niks in die ondervindings van die mens wat meer asemrowend is as die bespieëling van hierdie onafgebroke kavalkade van lewende wesens wat almal met 'n kortstondige bestaan die oppervlak van ons klein planeet versier het nie. In 'n oneindige prosessie het plante en diere versprei, vermenigvuldig en weer verdwyn; elkeen was vir 'n vlugtige tydjie deel van die ewigdurende proses wat ons lewe noem. Maar hierdie uiterlike siening is slegs een faset van die misterie en die wonder en skoonheid van dit alles, want binne-in en deur en rondom die liggame van elkeen van hierdie wesens het die asem van lewe gepols. Met in komplekse en verbysterende maaswerk van ingewikkelde chemiese en fisiese en biologiese veranderinge in wisselwerking met mekaar is die dun lewensdraad wat die organismes onderling met mekar verbind, gevorm ell in stand gehou (Ryke, 1966).

Met skepping deur eovlusie kon energie, stof, mikroörgamisme; plant, dier en mens voortgebring word. Sy skepping is nie staties nie, maar in dinamiese wonderwerk warin daar gedurig veranderinge plaasvind. Wie is geregverdig om iemand te verketter wat die evolusieproses as deel van God se wonderbaarlike skepping sien? Oor die meganismes van evolusie is daar ruim geleentheid om van mekar te verskil, maar dan 
moet dit op in wetenskaplike vlak geskied (Ryke, 1982). Aan die ander kant, is diegene wat in die evolusieverskynsel niks meer of anders sien nie as die stoflike en die fisies-kousale wette waraan dit onderhewig is, besig om die stoflike te verabsoluteer. In 'n wetenskap wat lewe ondersoek en wat hom van sy beperkings bewus is, moet daar altyd plek wees vir die onbegryplike, die misterie en die wonder.

Omdat daar soveel verskillende interpretasies van sowel Bybelse gegewens en uitsprake as wetenskaplike gegewens is, en in die toekoms nog sal wees, is 'n pleidooi vir wetenskaplike en godsdienstige verdraagsaamheid seker nie onvanpas nie. Verdraagsaamheid beteken nie dat 'n mens jou eie opvattings prysgee of jou geloof verwater nie. Dit beteken bloot erkenning van en respek vir die beperktheid van jou eie insigte en dié van ander. 'n Persoon wat op geloofsgronde 'n letterlike interpretasie van Genesis 1 aanvaar, het net soveel religieuse reg op sy standpunt as iemand wat skepping deur evolusie as 'n moontlikheid aanvaar. Hulle uitgangspunt is dieselfde - dis slegs die begrip van die skeppingswyse wat verskil, en daaroor laat die Bybel hom nie uit nie. En albei is dit hartlik eens dat die heelal in die algemeen en die aarde in besonder vit skeppingswonders bestaan.

BIBLIOGRAFIE

BARR, J. 1984. Escaping from fundamentalism. London: SCM Press.

BROOKS, D.R. \& WILEY, E.O. 1984 Evolution as an entropic phenomenon. (In Pollard, J.W., red. Evolutionary theory. Chichester: Wiley. p 141-171.)

COOKE, R.M. 1983. Geloof in wetenskap. Inleiding tot de methoden van wetenschapsbeoefening. Assen: Van Gorcum.

DARWIN, C. 1859. On the origin of species, by means of natural selection, or the preservation of favoured races in their struggle for life. London: Murray. 
DOBZHANSKY, T. 1973. Nothing in biology makes sense except in the light of evolution. Amer. Biol. Teacher 35:125-129.

FUTUYMA, D.J. 1983. Science on trial: The case for evolution. New York: Pantheon.

GHISELEN, M.T. 1984. The triumph of the Darwinian method. London: Univ. Chicago Press.

GILLESPIE, N.C. 1979. Charles Darwin and the problem of creation. London: Univ. Chicago Press.

GISH, D.T. 1978. The fossils say nol San Diego: Creation-Life Publishers.

GODFREY. L., red. 1985. What Darwin began. Modern Darwinian and non-Darwinian perspectives of evolution. London: Allyn and Bacon.

GRIESMER, J. 1985. Philosophy of science and the scientific method. Amer. Biol. Teacher 47:211-215.

HITCHING, F. 1982. The neck of the giraffe or where Darwin went wrong. London: Pan Books.

JORDAAN, E. \& LOOTS, G.C. 1984. A view of evolution by a Christian biologist. Koers $49(4): 426-472$.

JUKES, T.H. 1984. The creationist challenge to science. Nature $308: 398-400$

KEHOE, A.B. 1985. Modern antirevolusionism: The scientific creationists. IIn Godfrey, L R., red. What Darwin began. London: Allyn and Bacon. P 165-185.)

KENKEL, L.A. 1985. A case against scientific creationism: A look at content issues. Science Education 69:59-68. 
KITCHER, P. 1982. Abusing sceince: The case against creationism. Cambridge, Mass.: MIT Press.

KOFAHL, R.E. E SEGRAVES, K.L. 1975. The creation explanation. Wheaton: Harold Shaw.

LEVER, J. 1956. Creatie en evolutie. Wageningen. Zomer en Keunings.

LEVER, J. 1969. Waar blijven we? Een bioloog over de wording van dese aardse werkelijkheid. Kampen: J.H. Kok.

LEWIN, R. 1984. A tale with many connections. (In Montagu, A., red. Science and creation. Oxford Univ. Press. P VII-XVII.)

MARSDEN, G.M. 1983. Creation versus evolution: no middle way. Nature 305:571-574.

MARSDEN, G.M. 1984. Understanding fundamentalist views of science. (In Montagu, A., red. Science and creationism. Oxford Univ. Press. p 95-116.)

MAY, R.M. 1984. Creation, evolution and high school texts. (In Montagu, A., red. Science and creationism. Oxford Univ. Press. P 306-310.)

MAYER, W.V. 1984. The arrogance of ignorance - Ignoring the ubiquitious. Amer. Zool. 24:423-431.

MAYR, E. 1961. Cause and effect in biology. Sceince 134:1501-1506.

MILLER, K.R. 1982. Special creation and the fossil record: The central fallacy. Amer. Biol. Teacher 44:85-89.

MILLER, K.R. 1984. Scientific creationism versus evolution: The mislabeled debate. (In Montagu. A., red. Science and creationism. Oxford Univ. Press. P 18-63.) 
MONTAGU, A., red. 1984. Science and creationism. London: Oxford Univ. Press.

MORRIS, H.M. 1946. That you might believe. Chicago: Good Books.

MORRIS, H.M. 1966. Sutdies in the Bible and Science. Philadelphia: Lippincott.

MORRIS, H.M. 1972a. The remarkable birth of planet Earth. San Diego: Creation-Life Publishers.

MORRIS, H.M. 1972b. Biblical cosmology and modern science. New Jersey: Craig, Nutley.

MORRIS, H.M. 1974. Scientific creationism. San Diego: Creation-Life Publishers.

MORRIS, H.M. 1975. The troubled waters of evolution. San Diego: Creation-Life Publishers.

MORRIS, H.M. 1978. The beginning of the world. Denver: Accent.

MOYER, W.A. 1981. Arguments for maintaining the integrity of science education. Amer. Biol. Teacher 43:380-381.

NEWELL, N.D. 1982. Creation and evolution: Myth or reality? New York: Columbia Univ. Press.

OVERTON, W.R. 1984. Decision of the court. (In Montagu, A., red. Science and creationism. Oxford Univ. press. p 365-397.)

PARKER, G.E. 1980. Dry bones. San Diego: Creation-Life Publieshers.

POPPER, K.R. 1968. The logic of scientific discovery. New York: Harper Torchbooks.

$-33$ 
POPPER, K.R. 1978. Natural selection and the emergence of mind. Dialection 32:339-355.

RIDDIFORD, A. E PENNY, D. 1984. The scientific status of evolutionary theory. (In Pollard, J.W., red. Evolutionary theory. Chichester: wiley. p 1-38.)

ROOT-BERNSTEIN, R. 1984. On defining a scientific theory: Creationism considered. (In Montagu, A., red. Science and creationism. Oxford Univ. Press. p 64-94.)

RUSE, M. 1979. Falsifiability, consilience,.. and systematics. Syst. Zool. 28:530-536.

RUSE, M. 1984. A philosopher's day in court. (In Montagu, A., red. Science and creationism. Oxford Univ. Press. p 311-342.)

RYKE, P.A.J. 1966. Die oorsprong en evolusie van lewe. Publ. Univ. Noorde Reeks B, Nr. 3:1-18.

RYKE, P.A.J. 1982. Dierkunde. 'n Funksionele benadering. Durban: Butterworth.

RYKE, P.A.J. E BOTHA, P.J. 1966. Die invloed van die moderne biologie: Molekulère biologie en die evolusievraagstuk. Perspektief $5(2$ ( 3):31-47.

SCHUURMAN, E. 1980. Creation and science: Fundamental questions concerning evolutionisin and creationism. Theological Forum 8(2): 1-10; 24-26.

SEGRAVES, K.L. 1975. The great dinosaur mistake. San Diego: Beta Books.

SETtle, T. 1979. Popper on "when is a science not a science?" Syst. Zool. 28:521-529. 
WHITE, A.D. 1896. A history of the warfare of science with theology in Christendom. 2 vol. Herdruk 1960. New York: Dover.

WHITCOMB, J.C. \& MORRIS, H.M. 1980. The Genesis flood. New Jersey: Presbyterian and Reformed Publ. Co.

WILLIAMS, M.B. 1985. The scientific status of evolutionary theory. Amer. Biol. Teacher 47:205-210. 